\title{
Thrombin Peptide (TP508) Promotes Adipose Tissue-Derived Stem Cell Proliferation via PI3 Kinase/Akt Pathway
}

\author{
Susanne Freyberg Yao-Hua Song Fabian Muehlberg Eckhard Alt \\ Department of Molecular Pathology, University of Texas MD Anderson Cancer Center, Houston, Tex., USA
}

\section{Key Words}

Proliferating capacity $\cdot$ Stem cells $\cdot$ Wound healing

\begin{abstract}
A synthetic peptide representing the receptor-binding domain of human thrombin (TP508) promotes angiogenesis and accelerates wound healing in animal models. However, the mechanisms underlying the therapeutic effects of TP508 have not been clearly defined. In this study, we set out to determine whether TP508 could stimulate stem cell proliferation. Adipose tissue-derived stem cells (ASCs) were incubated with TP508 $(5 \mu \mathrm{g} / \mathrm{ml})$ and cell proliferation was determined by bromodeoxyuridine (BrdU) incorporation. Our data showed that TP508 treatment significantly stimulated BrdU incorporation in ASCs ( $p<0.01$ ). The increased BrdU incorporation induced by TP508 was abolished by the PI3 kinase (PI3K) inhibitor LY294002 at $50 \mu \mathrm{M}$. Western blot analysis of ASCs revealed increased phosphorylation of Akt in response to TP508 when compared to unstimulated controls. These results indicate that TP508 exerts proliferative effects on ASCs via the PI3K/Akt pathway.
\end{abstract}

Copyright $\odot 2008$ S. Karger AG, Basel

\section{Introduction}

Thrombin is a serine protease that is activated upon tissue damage during the ongoing coagulation cascade [1-3]. Thrombin exerts cellular effects via G-protein-

\section{KARGER}

Fax +41613061234

E-Mail karger@karger.ch

www.karger.com

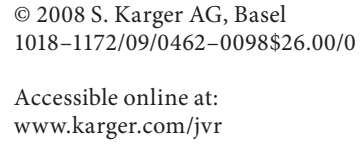

coupled protease-activated receptors (PARs), in addition to its role in the formation of a blood clot. PARs are activated by proteolytic cleavage of a specific site in the extracellular domain, which, in turn, acts as a ligand. Among the four known PAR receptors, thrombin activates PAR-1, PAR-3 and PAR-4 but not PAR-2. However, growing evidence suggests that PAR-2 may mediate thrombin signaling by complexing with PAR-1 and PAR4 [4-6]. TP508 is a peptide which represents residues 508-530 of human prothrombin and was originally identified for its ability to compete for high-affinity $\alpha$-thrombin binding to fibroblasts and to enhance proliferation of fibroblasts co-stimulated with proteolytically active $\alpha$ thrombin or molecules that activate downstream signaling events, normally elicited by PAR-1 activation [7-11]. TP508 binds to high-affinity thrombin receptors and mimics cellular effects of thrombin at sites of tissue injury [11]. Unlike thrombin, TP508 has no enzymatic activity and does not promote or interfere with blood coagulation [9].

Previous studies have shown that TP508 promotes wound healing in various animal models. In full-thickness incisional wounds in rats, a single topical application of TP508 increased the breaking strength of wounds by approximately $82 \%$ over saline controls when measured at day 7 postincision [12]. Significant effects of TP508

S. Freyberg and Y.-H. Song contributed equally to this work.

Prof. Eckhard Alt

Department of Molecular Pathology, University of Texas

MD Anderson Cancer Center

SCRB2, Box 951, 7435 Fannin Street, Houston, TX 77054 (USA)

Tel. +1 713834 6102, Fax +1 713834 6103, E-Mail ealtmd@aol.com 
were also seen on incisional wounds in rats with radiation-induced healing impairment [13].

Treatment of full-thickness excisional wounds in normal rats with a single topical application of TP508 reproducibly accelerates wound closure (40\% greater in TP508treated than vehicle-treated wounds) [11]. TP508 treatment of ischemic flap wounds restored the normal rapid resolution of the inflammatory phase [14]. TP508 also accelerated repair of rat fresh fractures [15] and promoted bone formation in rabbit critical-size segmental bone defects [16] and in a rabbit model of distraction osteogenesis [17]. TP508 stimulates healing of diabetic foot ulcers in a placebo-controlled phase I/II study [18].

The mechanisms underlying the beneficial effect of TP508 remain largely unknown. Some studies have indicated that angiogenesis may be involved [14]. We have shown previously that adipose tissue-derived stem cells (ASCs) produce a significant amount of VEGF which is required for angiogenesis [19]. To define the mechanisms of TP508-mediated wound healing, we set out to determine whether TP508 could stimulate the proliferation of ASCs which in turn promote wound healing.

\section{Materials and Methods}

\section{Isolation and Culture of Human ASCs}

Subcutaneous adipose tissue was obtained from 3 patients undergoing elective operations (not liposuctions) following the University Institutional Guidelines. Cells were isolated from the fat tissue as described previously [20] with modifications. Fat tissue was minced and incubated for $90 \mathrm{~min}$ at $37^{\circ} \mathrm{C}$ on a shaker with Liberase Blendzyme 3 (Roche) at a concentration of 4 units/g of fat tissue in PBS. The digested tissue was sequentially filtered through 100- and $40-\mu \mathrm{m}$ filters (Fisher Scientific) and centrifuged at $450 \mathrm{~g}$ for $10 \mathrm{~min}$. The supernatant-containing adipocytes and debris was discarded and the pelleted cells were washed twice with Hanks' balanced salt solution (Cellgro) and finally resuspended in growth media. Growth media contained alpha modification of Eagle's medium ( $\alpha$ MEM, Cellgro), 20\% FBS (Atlanta Biologicals), $2 \mathrm{mM}$ glutamine (Cellgro), $100 \mathrm{U} / \mathrm{ml}$ penicillin with $100 \mu \mathrm{g} / \mathrm{ml}$ streptomycin (Cellgro). Plastic adherent cells were designated human ASCs (hASCs) and grown in Nunclon culture vials (Nunc) at $37^{\circ} \mathrm{C}$ in a humidified atmosphere containing $5 \%$ $\mathrm{CO}_{2}$ followed by daily washes to remove red blood cells and nonattached cells.

\section{Cell Proliferation}

Cell proliferation was studied using a colorimetric bromodeoxyuridine (BrdU) kit (Roche Diagnostics) according to the manufacturer's instructions. LY294002 was purchased from Cell Signaling (Danvers, Mass., USA). $2 \times 10^{4}$ hASCs at passage 2 were seeded in 96-well plates for $24 \mathrm{~h}$ in serum-free medium $(\alpha$ MEM). After $24 \mathrm{~h}$ incubation, either human thrombin (Sigma) or TP508 (MD Anderson Cancer Center peptide core lab) was added to cells and the incubation continued for another $24 \mathrm{~h}$. BrdU solution was then added into the medium. The medium was discarded after $2 \mathrm{~h}$, and cells were fixed with FixDenat solution for $30 \mathrm{~min}$ at room temperature. After removing FixDenat, cells were incubated with $100 \mu \mathrm{l}$ freshly diluted 1:100 anti-BrdU peroxidase solution for $30 \mathrm{~min}$. The cells were washed 3 times, $100 \mu \mathrm{l}$ of substrate solution was added to incubate for $30 \mathrm{~min}$ at room temperature, $25 \mu \mathrm{l} 1 \mathrm{M} \mathrm{H}_{2} \mathrm{SO}_{4}$ was added to terminate the reaction, and then absorbance at $450 \mathrm{~nm}$ was measured in an ELISA plate reader.

\section{Analysis of mRNA Expression of Thrombin Receptor Using} Reverse Transcription-Polymerase Chain Reaction Technique

Total RNA was extracted from hASCs using Trizol reagents (Life Technologies). cDNA was synthesized from $1 \mu \mathrm{g}$ total RNA using SuperScript II reverse transcriptase (Life Technologies) in $20 \mu \mathrm{l}$ according to the manufacturer's instructions. cDNA samples were subjected to polymerase chain reaction (PCR) amplification using AccuPrime SuperMix I (Invitrogen) with specific primers for human thrombin receptor (F: 5'-TATTTGACCAGCTCCTGGCTGACA-3'; R: 5'-AACAGCAGCTGACAGGAACAAAGC-3'). Control reactions consisted of the above-mentioned PCR amplification mix with primers but no cDNA template. PCR was performed with an Eppendorf mastercycler gradient (Eppendorf). Cycles were programmed as follows: $94^{\circ} \mathrm{C}$ for $10 \mathrm{~min}, 35$ cycles of $30 \mathrm{~s}$ denaturation at $94^{\circ} \mathrm{C}, 30 \mathrm{~s}$ at annealing temperature $\left(55^{\circ} \mathrm{C}\right), 60 \mathrm{~s}$ extension at $72^{\circ} \mathrm{C}$, with a final extension at $72^{\circ} \mathrm{C}$ for $5 \mathrm{~min}$. The product size was confirmed by running $10 \mu \mathrm{l}$ of sample on $1.5 \%$ agarose gel electrophoresis.

\section{Western Blot}

hASCs were lysed in RIPA lysis buffer (Upstate) including protease inhibitor cocktail (Roche Diagnostics) according to the manufacturer's instructions. The proteins were separated on sodium dodecyl sulfate/polyacrylamide gel electrophoresis gels and then transferred to polyvinylidene difluoride membranes. After blocking with $5 \%$ nonfat milk, the membranes were incubated for $1 \mathrm{~h}$ at room temperature with rabbit anti-p-Akt (Cell Signaling). Following incubation with goat anti-rabbit horseradish peroxidase secondary antibody (Pierce), labeled proteins were detected using the SuperSignal chemiluminescence detection system (Pierce). For PAR-1, goat anti-PAR-1 and donkey anti-goat IgGhorseradish peroxidase were purchased from R\&D Systems.

Data Analysis

All values are presented as means \pm standard deviation. Statistical analysis was performed using Student's t tests. A level of $\mathrm{p}<0.05$ was considered as statistically significant.

\section{Results}

\section{ASCs Express Thrombin Receptor}

The ASCs are plastic-adherent, spindle-shaped cells (fig. 1). These cells are positive for CD44, CD90, CD105 and negative for CD11b, CD14, CD34, CD45 and HLADR as we have described previously $[21,22]$. We also 


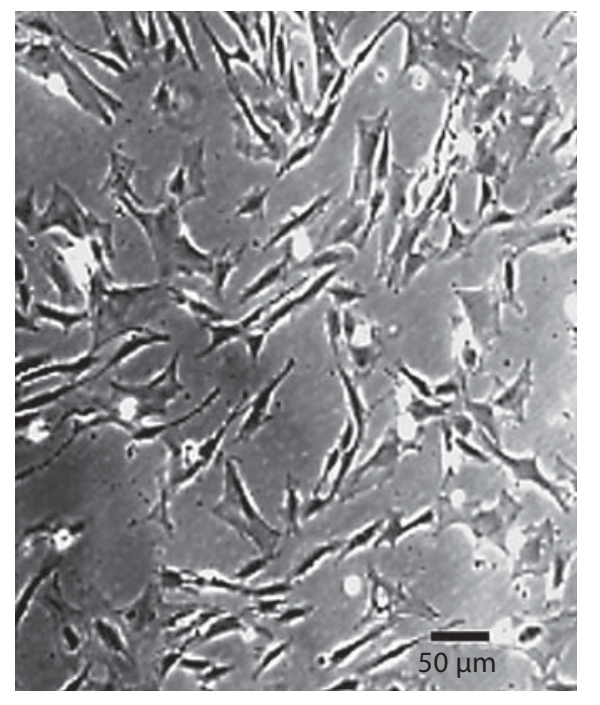

Fig. 1. Phase contrast photomicrographs of hASCs at passage two. hASCs are spindle shaped and plastic adherent.

showed previously that the ASCs are multipotent [21, 22].

Reverse transcription-PCR was performed to detect thrombin receptor mRNA. The PCR product showed the expected size (fig. 2a) and its identity was confirmed by sequencing. A blast search of the GeneBank identified the PCR product as Homo sapiens coagulation factor II (thrombin) receptor (F2R) (NM_001992). Western blot analysis using anti-PAR-1 antibody detected a clear band of $47 \mathrm{kDa}$ with the expected size for human PAR-1 (fig. 2b).

\section{Effects of TP508 on BrdU Incorporation}

Incubation of $2 \times 10^{4} \mathrm{ASC}$ with thrombin resulted in an increase of BrdU incorporation compared to the control (fig. 3). Similarly, incubation of ASC with TP508 also resulted in an increase of BrdU incorporation (fig. 4). The increased BrdU incorporation induced by TP508 was abolished by PI3 kinase (PI3K) inhibitor LY294002 at 50 $\mu \mathrm{M}$. LY294002 alone has no effect on BrdU incorporation.

\section{Effects of TP508 on Akt Phosphorylation}

ASCs were grown for $16 \mathrm{~h}$ in serum-free medium, and then treated with TP508 at a concentration of $5 \mu \mathrm{g} / \mathrm{ml}$ for $1 \mathrm{~h}$. Western blot analysis of ASCs revealed increased phosphorylation of Akt in response to TP508 when compared to unstimulated controls (fig. 4). The protein level of total Akt was not altered by TP508 treatment (fig. 5).

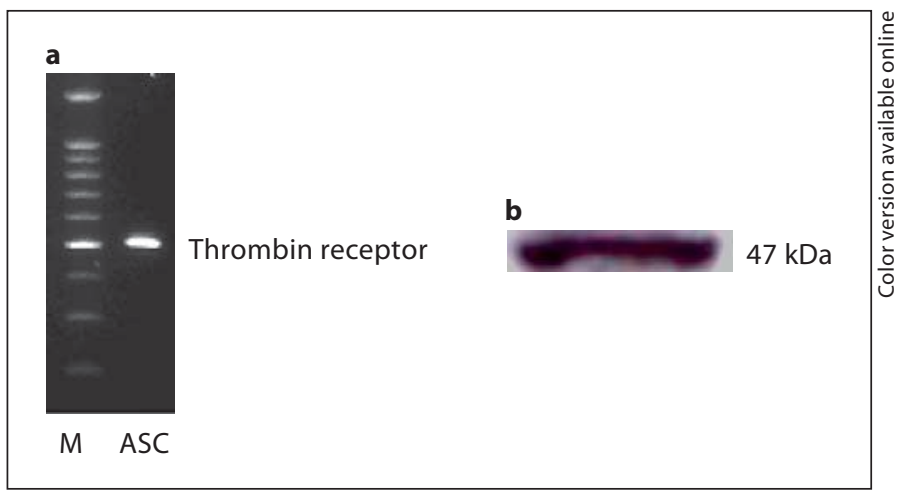

Fig. 2. Human ASCs express thrombin receptor. a mRNA expression of thrombin receptor from hASCs by RT-PCR. $\mathrm{M}=\mathrm{DNA}$ marker (100-bp ladder). b PAR-1 expression by Western blot.

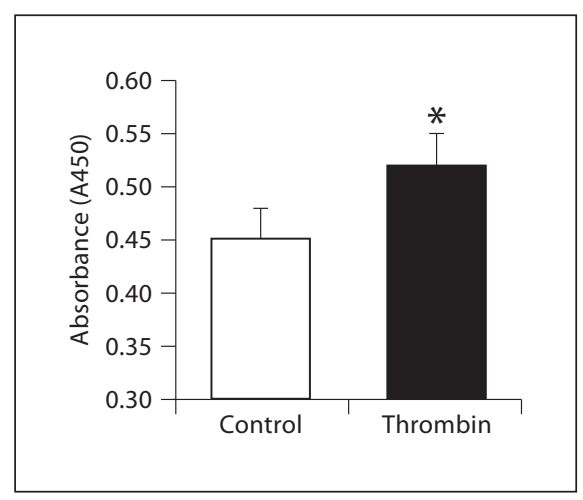

Fig. 3. Thrombin induces BrdU incorporation in ASCs. Proliferative effects were assessed by BrdU incorporation. Thrombin: $1 \mu \mathrm{g} / \mathrm{ml} .{ }^{*} \mathrm{p}<0.05$.

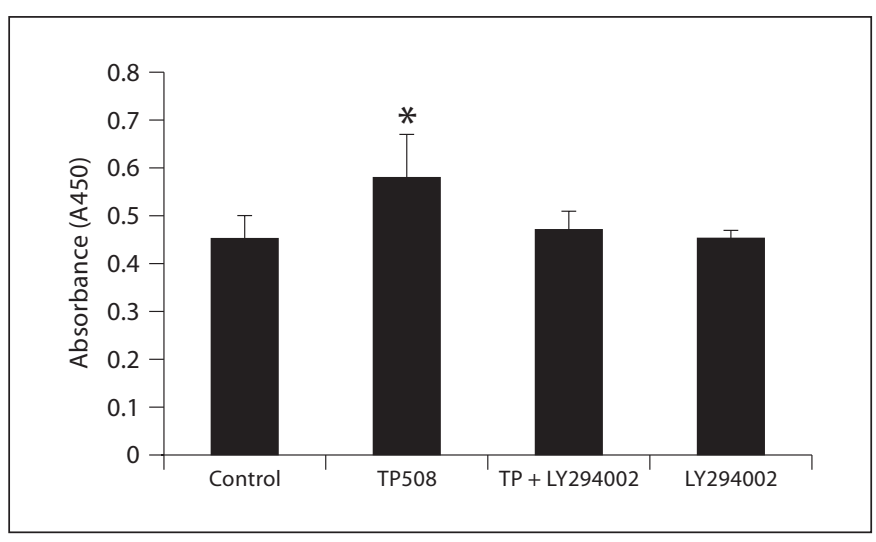

Fig. 4. TP508 induces BrdU incorporation in ASCs. Proliferative effects were assessed by BrdU incorporation. TP $=\mathrm{TP} 508$ at $5 \mu \mathrm{g} /$ $\mathrm{ml} ; \mathrm{LY} 294002=\mathrm{PI} 3 \mathrm{~K}$ inhibitor at $50 \mu \mathrm{M} .{ }^{*} \mathrm{p}<0.05$. 


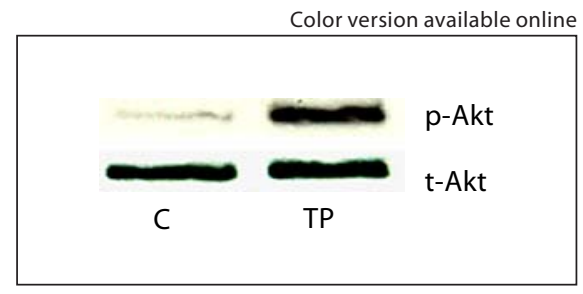

Fig. 5. Western blot analysis of Akt. $\mathrm{C}=$ Control; $\mathrm{TP}=\mathrm{TP} 508$ at $5 \mu \mathrm{g} / \mathrm{ml}$ incubated for $1 \mathrm{~h}$ with ASC.

\section{Discussion}

The present study demonstrates that ASC express the thrombin receptor. To our knowledge, the presence of thrombin receptor on ASCs has never been reported before. However, PAR-1 is widely distributed and has already been described on CD34+ hematopoietic stem cells and on endothelial progenitor cells. Smadja et al. [23] showed that human late endothelial progenitor cells express PAR-1, and that PAR-1 activation induces proliferation, migration and increased capillary-like structure formation in Matrigel. Tarzami et al. [24] showed that thrombin or PAR-1-activating peptide produced a 2- to 3 -fold increase in the total number of endothelial progenitor cells.

It has been shown that thrombin induces increased expression and secretion of VEGF from human FS4 fibroblasts, DU145 prostate cells and CHRF megakaryocytes via the PI3K pathway [25]. However, in endothelial cells, the stimulation by thrombin as well as thrombin peptide led to DNA synthesis through activation of the ERK pathway [26]. Kataoka et al. [27] showed that PAR1 is required for ERK activation in response to low concentrations of thrombin. Samdja et al. [28] showed that PAR1 -induced proliferation of endothelial progenitor cells involves angiopoietin 2, which in turn activates Akt pathway [29]. It has also been shown that immobilized TP508 peptide stimulated phosphorylation of mitogen-activated protein kinases and focal adhesion kinase and supported $\alpha_{\mathrm{v}} \beta_{3}$ integrin-dependent endothelial cell attachment and haptotactic migration [30].

In this in vitro model, TP508 promote the proliferation of ASC and the proliferative effect of TP508 was reduced by PI3K inhibitor. These data suggest that TP508 exerts its proliferative effects involving PI3K/Akt signaling.

To further investigate the mechanism of TP508-induced, PI3K/Akt-dependent cell proliferation, a Western blot analysis of the phosphorylated protein was performed. Phosphorylation of Akt was increased, whereas the protein levels of total Akt were not altered. Our findings are in line with a previous report that TP508 promotes cell growth and wound healing via PI3K/Akt pathway [31].

Consistent with in vivo observations that TP508 promoted neovascularization of the wound tissues $[10,14$, $32,33]$, our data showed that TP508 promotes ASC proliferation. We have shown previously that ASCs differentiated into vascular cells when injected into infarcted hearts [34]. In light of previous reports that TP508 promotes wound healing [12-18], our findings suggest that the beneficial effect of TP508 may be mediated by stem cells. To this end, it has been shown that autologous mesenchymal stem cells increase vascularity and reduce wound size of nonhealing diabetic ulcer [35]. Importantly, a recent report showed that TP508 also stimulates healing of diabetic foot ulcers in a placebo-controlled phase I/II study [18]. It would be interesting to find out whether the beneficial effects of TP508 on diabetic ulcer are mediated by endogenous stem cells.

\section{Acknowledgment}

This work has been supported in part by grant 543102 from the Alliance of Cardiovascular Researchers (to E.A.).

\section{References}

1 Dery O, Corvera CU, Steinhoff M, Bunnett NW: Proteinase-activated receptors: novel mechanisms of signaling by serine proteases. Am J Physiol 1998;274:C1429-C1452.

2 Coughlin SR: Thrombin signalling and protease-activated receptors. Nature 2000;407: 258-264.

3 Macfarlane SR, Seatter MJ, Kanke T, Hunter GD, Plevin R: Proteinase-activated receptors. Pharmacol Rev 2001;53:245-282.
4 Kahn ML, Zheng YW, Huang W, Bigornia V, Zeng D, Moff S, Farese RV Jr, Tam C, Coughlin SR: A dual thrombin receptor system for platelet activation. Nature 1998;394:690694.

-5 Nakanishi-Matsui M, Zheng YW, Sulciner DJ, Weiss EJ, Ludeman MJ, Coughlin SR: PAR3 is a cofactor for PAR4 activation by thrombin. Nature 2000;404:609-613.
6 O'Brien PJ, Prevost N, Molino M, Hollinger MK, Woolkalis MJ, Woulfe DS, Brass LF: Thrombin responses in human endothelial cells. Contributions from receptors other than PAR1 include the transactivation of PAR2 by thrombin-cleaved PAR1. J Biol Chem 2000;275:13502-13509. 
7 Carney DH, Herbosa GJ, Stiernberg J, Bergmann JS, Gordon EA, Scott D, Fenton JW 2nd: Double-signal hypothesis for thrombin initiation of cell proliferation. Semin Thromb Hemost 1986;12:231-240.

$\checkmark 8$ Carney DH, Redin W, McCroskey L: Role of high-affinity thrombin receptors in postclotting cellular effects of thrombin. Semin Thromb Hemost 1992;18:91-103.

>9 Glenn KC, Frost GH, Bergmann JS, Carney $\mathrm{DH}$ : Synthetic peptides bind to high-affinity thrombin receptors and modulate thrombin mitogenesis. Pept Res 1988;1:65-73.

10 Sower LE, Payne DA, Meyers R, Carney DH: Thrombin peptide, TP508, induces differential gene expression in fibroblasts through a nonproteolytic activation pathway. Exp Cell Res 1999;247:422-431.

-11 Stiernberg J, Norfleet AM, Redin WR, Warner WS, Fritz RR, Carney DH: Acceleration of full-thickness wound healing in normal rats by the synthetic thrombin peptide, TP508. Wound Repair Regen 2000;8:204215.

-12 Carney DH, Mann R, Redin WR, Pernia SD, Berry D, Heggers JP, Hayward PG, Robson MC, Christie J, Annable C, et al: Enhancement of incisional wound healing and neovascularization in normal rats by thrombin and synthetic thrombin receptor-activating peptides. J Clin Invest 1992;89:1469-1477.

$\checkmark 13$ Cromack DT, Porras-Reyes BH, Wee SS, Glenn KC, Purdy JA, Carney DH, Mustoe TA: Acceleration of soft tissue repair by a thrombin-derived oligopeptide. J Surg Res 1992;53:117-122.

-14 Norfleet AM, Huang Y, Sower LE, Redin WR, Fritz RR, Carney DH: Thrombin peptide TP508 accelerates closure of dermal excisions in animal tissue with surgically induced ischemia. Wound Repair Regen 2000; 8:517-529.

15 Wang H, Li X, Tomin E, Doty SB, Lane JM, Carney DH, Ryaby JT: Thrombin peptide (TP508) promotes fracture repair by upregulating inflammatory mediators, early growth factors, and increasing angiogenesis. J Orthop Res 2005;23:671-679.

-16 Sheller MR, Crowther RS, Kinney JH, Yang J, Di Jorio S, Breunig T, Carney DH, Ryaby JT: Repair of rabbit segmental defects with the thrombin peptide, TP508. J Orthop Res 2004;22:1094-1099.
Li G, Ryaby JT, Carney DH, Wang H: Bone formation is enhanced by thrombin-related peptide TP508 during distraction osteogenesis. J Orthop Res 2005;23:196-202.

18 Fife C, Mader JT, Stone J, Brill L, Satterfield K, Norfleet A, Zwernemann A, Ryaby JT, Carney DH: Thrombin peptide Chrysalin stimulates healing of diabetic foot ulcers in a placebo-controlled phase I/II study. Wound Repair Regen 2007;15:23-34.

19 Sadat S, Gehmert S, Song YH, Yen Y, Bai X, Gaiser S, Klein H, Alt E: The cardioprotective effect of mesenchymal stem cells is mediated by IGF-I and VEGF. Biochem Biophys Res Commun 2007;363:674-679.

20 Gimble J, Guilak F: Adipose-derived adult stem cells: isolation, characterization, and differentiation potential. Cytotherapy 2003; 5:362-369.

21 Bai X, Sadat S, Gehmert S, Alt E, Song YH: VEGF receptor Flk-1 plays an important role in c-kit expression in adipose tissue derived stem cells. FEBS Lett 2007;581:4681-4684.

22 Bai X, Ma J, Pan Z, Song YH, Freyberg S, Yan Y, Vykoukal D, Alt E: Electrophysiological properties of human adipose tissue-derived stem cells. Am J Physiol Cell Physiol 2007; 293:C1539-C1550.

23 Smadja DM, Bieche I, Uzan G, Bompais H, Muller L, Boisson-Vidal C, Vidaud M, Aiach M, Gaussem P: PAR-1 activation on human late endothelial progenitor cells enhances angiogenesis in vitro with upregulation of the SDF-1/CXCR4 system. Arterioscler Thromb Vasc Biol 2005;25:2321-2327.

24 Tarzami ST, Wang G, Li W, Green L, Singh JP: Thrombin and PAR-1 stimulate differentiation of bone marrow-derived endothelial progenitor cells. J Thromb Haemost 2006;4: 656-663.

25 Huang YQ, Li JJ, Hu L, Lee M, Karpatkin S: Thrombin induces increased expression and secretion of VEGF from human FS4 fibroblasts, DU145 prostate cells and CHRF megakaryocytes. Thromb Haemost 2001;86: 1094-1098.

26 Olivot JM, Estebanell E, Lafay M, Brohard B, Aiach M, Rendu F: Thrombomodulin prolongs thrombin-induced extracellular signal-regulated kinase phosphorylation and nuclear retention in endothelial cells. Circ Res 2001;88:681-687.
27 Kataoka H, Hamilton JR, McKemy DD, Camerer E, Zheng YW, Cheng A, Griffin C, Coughlin SR: Protease-activated receptors 1 and 4 mediate thrombin signaling in endothelial cells. Blood 2003;102:3224-3231.

28 Smadja DM, Laurendeau I, Avignon C, Vidaud M, Aiach M, Gaussem P: The angiopoietin pathway is modulated by PAR-1 activation on human endothelial progenitor cells. J Thromb Haemost 2006;4:2051-2058.

29 Hildbrand P, Cirulli V, Prinsen RC, Smith KA, Torbett BE, Salomon DR, Crisa L: The role of angiopoietins in the development of endothelial cells from cord blood CD34+ progenitors. Blood 2004;104:2010-2019.

30 Tsopanoglou NE, Papaconstantinou ME, Flordellis CS, Maragoudakis ME: On the mode of action of thrombin-induced angiogenesis: thrombin peptide, TP508, mediates effects in endothelial cells via alphavbeta3 integrin. Thromb Haemost 2004;92:846857.

31 Li X, Wang H, Touma E, Qi Y, Rousseau E, Quigg RJ, Ryaby JT: TP508 accelerates fracture repair by promoting cell growth over cell death. Biochem Biophys Res Commun 2007;364:187-193.

-32 Naldini A, Carraro F, Baldari CT, Paccani SR, Bernini C, Keherly MJ, Carney DH: The thrombin peptide, TP508, enhances cytokine release and activates signaling events. Peptides 2004;25:1917-1926.

33 Norfleet AM, Bergmann JS, Carney DH: Thrombin peptide, TP508, stimulates angiogenic responses in animal models of dermal wound healing, in chick chorioallantoic membranes, and in cultured human aortic and microvascular endothelial cells. Gen Pharmacol 2000;35:249-254.

34 Valina C, Pinkernell K, Song YH, Bai X, Sadat S, Campeau RJ, Le Jemtel TH, Alt E: Intracoronary administration of autologous adipose tissue-derived stem cells improves left ventricular function, perfusion, and remodelling after acute myocardial infarction. Eur Heart J 2007;28:2667-2677.

35 Vojtassak J, Danisovic L, Kubes M, Bakos D, Jarabek L, Ulicna M, Blasko M: Autologous biograft and mesenchymal stem cells in treatment of the diabetic foot. Neuro Endocrinol Lett 2006;27(suppl 2):134-137. 